\title{
Philosophical Aspects of Legal Discovery (Rechtsviding) in the Testing of Law by the Constitutional Court of The Republic of Indonesia
}

\author{
Dany Rimawan \\ Student of Doctoral Program in Law, Borobudur University, Jakarta Indonesia \\ Email: danyrimawan@yahoo.com \\ H. Faisal Santiago \\ Borobudur University, Faculty of Law, Jakarta Indonesia \\ H. Azis Budianto \\ Borobudur University, Faculty of Law, Jakarta Indonesia
}

\begin{abstract}
A state based on law, the principle of the rule of law guarantees certainty, truth, and legal protection with the core of truth and justice. The establishment of the judicial institution of the Constitutional Court, the Republic of Indonesia is a manifestation of the practice of state democracy based on the constitution in Indonesia. Based on the authority possessed by the Constitutional Court, philosophically, legal discovery in judicial review is a form of constitutionally legitimized decision, if the law is contrary to the 1945 Constitution.
\end{abstract} Keywords: Philosophical Aspects, Judicial Review, Constitutional Court

DOI: $10.7176 / \mathrm{JLPG} / 115-13$

Publication date: November $30^{\text {th }} 2021$

\section{Introduction}

In Southeast Asia, Indonesia is currently recognized as the best model country in democracy. The practice of constitutional democracy in Indonesia is currently experiencing significant progress since the start of the democratization process following the fall of President Soeharto on May 21, 1998. The current practice of democracy has relatively met the principles of modern constitutional democracy due to the enforcement of checks and balances mechanisms and the guarantee of rights - constitutional rights of citizens. As a country based on law (rechtstaat), since the reform era, the Indonesian state has been more appreciative in realizing the rule of law.

Indonesia, as a country based on law, the state of law guarantees certainty, principles, and legal protection with the core of truth and justice. Certainty, application, and legal protection demand, among other things,. The State of Indonesia, which in the explanation of the 1945 Constitution of the Republic of Indonesia is declared as a country based on law (rechtstaat), then by itself, that within the framework of living as a nation and state, all people must comply with applicable laws.

The law is for the most part by the power or authority that is determined. This is almost always the apparatus of rulers (overheids-organn) of a concrete legal and state order. The establishment of the judicial institution of the Constitutional Court, the Republic of Indonesia further strengthens the practice of constitutional democracy in Indonesia. The existence of the Constitutional Court is a new phenomenon in the world of state administration. In general, countries with established democratic systems and practices do not recognize or do not establish a Constitutional Court which is independent in addition to the Supreme Court. The establishment of the Constitutional Court is generally carried out by a state that is free from authoritarian rule and begins democratization.

Indonesia, which started the democratization process in the Reformation Era, saw the need to establish a Constitutional Court institution. This is an important breakthrough to practice constitutional democracy in Indonesia. Prior to the establishment of the Constitutional Court which began operating in August 2003, Indonesia did not have a judicial institution that had the authority to examine laws, if the laws conflicted with the 1945 Constitution.

Prior to the establishment of the Constitutional Court, the judicial review authority of the Supreme Court was only limited to examining regulations under the law against the law. The Supreme Court is not authorized to conduct a judicial review of the constitutionality of a law against the 1945 Constitution, even though the law is contrary to the 1945 Constitution. As a result, laws during the New Order era were dominated by the executive from planning to implementation. its implementation, even its ratification, is highly dependent on the President.

After the amendment or amendment to the 1945 Constitution of the Republic of Indonesia from 1999 to 2002 and then proposed with the establishment of the Constitutional Court in August 2003, the above doctrine is 
no longer valid. Indonesia began to establish itself to apply the principles of modern constitutional democracy. Thus, laws that are deemed to have violated the 1945 Constitution of the Republic of Indonesia after the amendments can be brought to the Constitutional Court for constitutional review by a constitutional judge.

According to Saldi Isra, the institutionalization of the mechanism for reviewing laws (judicial review) conducted by the Constitutional Court is one manifestation of the purification or purification of the government system after four times (1999-2002) amendments to the 1945 Constitution. The Constitutional Court has implemented Its three powers are to decide the law on the 1945 Constitution, dispute the authority of state institutions, and take the results of general elections and then also include regional head elections after being given the authority to decide on constitutional regional head election disputes. The law has a certain form, a formal structure. We distinguish legal rules, legal figures and legal institutions (legal institutions). Into the rules of law are general rules (eg laws), concrete decisions (eg verdicts, government decisions or statutes) and legal principles.

To date, the Constitutional Court has received, examined, and decided on applications for judicial review, both formal and material examinations. From 2003 to 25 June 2008, 149 applications for judicial review were received by the Constitutional Court. After the trial process at the Constitutional Court, 37 cases were granted, 45 cases were rejected, 43 applications were not accepted, and 15 cases were withdrawn. This means that as many as 140 cases have been decided by the Constitutional Court and there are 9 cases remaining at that time. Judging from the number of laws applied for review to the Constitutional Court, there were recorded as many as 69 laws from various types of laws.

Furthermore, the data on judicial review at the Constitutional Court until December 31, 2010; the total is as follows: 2009, 90 cases, from 2010 to 31 December, 109 cases and 58 cases were decided, as well as laws that were tested 6 laws. Furthermore, from 2010 to December 31, 2019, 214 cases were decided or decided, 175 cases, and 17 laws were tested. From the background above, the formulation of the problem that must be studied in this paper is why the law in judicial review is the authority of the Constitutional Court?

\section{Research Methods}

The problem approach used in this paper is to use a normative juridical approach, namely library law research and because this research is carried out by having library materials. In this study, descriptive-analytical research will be used on the grounds that the results obtained from the literature study are then analyzed and discussed using a systematic flow of discussion. Thus, the results of the analysis and subsequent discussion are described to facilitate drawing conclusions and submitting suggestions

\section{Results And Discussion}

\section{a. The Authority to Review Laws by the Constitutional Court}

The more cases that are being tested by law, which are submitted to the Constitutional Court, show at least three important things.

1) The emergence of state constitutional awareness among Indonesian citizens about their constitutional rights that have been guaranteed by the 1945 Constitution. The existence of the Constitutional Court with its authority to examine the constitutionality of laws has provided access for Indonesian citizens to fight for their constitutional rights.

2) Many laws contradict the constitution and laws and regulations and injure the constitutional rights of Indonesian citizens. This is what then encourages parties who are harmed by the enactment of the law to apply for a judicial review of the law to the Court.

3) The large number of petitions for judicial review submitted to the Constitutional Court is one proof that the making of laws has not yet fully realized a good law.

The result, "I feel that the Constitutional Court is a place to accommodate the various weaknesses of the law". In some of the decisions on judicial review by the Constitutional Court, there are legal findings (rechtsvinding). This means that in several of its decisions the Constitutional Court has introduced legal discoveries (rechtsvinding). The implication is that the decisions of the Constitutional Court which have the dimension of legal discovery (rechtsvinding), raise pros and cons both among the public, as well as legal experts and practitioners.

As a state of law as in various countries in the world, since its founding as a judicial institution, namely the Constitutional Court on August 13, 2003 and started working on August 19, 2003, since then, Indonesia has officially had a judicial institution that conducts constitutional review of laws and regulations. This authority is legitimized based on the provisions of the 1945 Constitution after the amendment.

The birth of the Court is part of the political transition that is developing in Indonesia. In some cases, the direction of political transition is towards democracy, either by a democratic form of government that has been undermined by a dictatorial regime or through steps to form a new government, in which neither party from the previous regime was involved. The transition period from the era of the New Order government to the era of 
reform, including the background of the socio-political and legal conditions in Indonesia where deviations occurred and was not in accordance with the constitutional mandate. many invitations are not controlled much, so that in fact more are in control of their will. The behavior of the power holder in the name of the law is just a formality. For example, press freedom is restricted. Freedom of expression is also shackled. And even control over the law does not exist, or is identical to the law as if it has fulfilled the provisions of legal procedures because it has been made by an institution that has the authority.

The Constitutional Court which is given the authority to examine the constitutionality of laws which has the authority to review is the Supreme Court. Furthermore, the Supreme Court has only limited expertise in examining regulations under the law. Thus, there has been an empty space for reviewing constitutionality laws for quite a long time in the history of Indonesian constitutionalism. Another is that the task of the judge is not to examine the law, but to apply the law, and if the judge examines the reasons for the law, it will be contrary to the concept of supremacy of the People's Consultative Assembly (MPR).

The authority of the Supreme Court to conduct a judicial review was stated when the Constitution of the Republic of the United States of Indonesia (RIS) came into effect in 1949 in Articles 156, 157, and 158. However, the judicial review authority by the Supreme Court was only limited to reviewing the laws in force in the states. RIS against the RIS Constitution. While during the promulgation of the 1950 Provisional Constitution (UUDS 1950), which enforced the RIS Constitution, judicial review of the 1950 Constitution could not be carried out, there was no provision on judicial review and there was one state institution, including the Supreme Court, which was authorized to examine laws against the constitution.

The authority of the Supreme Court to materially examine the legislation under the law is through the Decree of the People's Consultative Assembly Number VI/MPR/1973 Article 11 paragraph (4). This provision was then included in Article 11 paragraph (4) of the MPR Decree Number II/MPR/1978, which was further included in Article 24A paragraph (1) of the Third Amendment of the 1945 Constitution (2001) and in the Law on Judicial Power ( Law Number 4 of 2004) and the Law on the Supreme Court (Law Number 5 of 2004). Furthermore, in the 1980s, an offer reappeared to submit a request to the Supreme Court to conduct a judicial review of the law, as previously proposed by Muhammad Yamin. However, this proposal failed again for the same reasons that Soepomo had put forward. Thus, the judicial review authority possessed by the Supreme Court remains limited to the examination of statutory regulations under the law. This means that judicial review of the constitutionality of laws can still be carried out in Indonesia during the constitutional period of the enactment of the 1945 Constitution before changes were made post-reformation in 1998. Regarding the need for constitutionality testing of laws, discourse and aspirations remain limited.

In the Reformation Era, the People's Consultative Assembly passed Decree Number III/MPR/2000 concerning Sources of Law and Order of Legislation which authorized the MPR to examine laws against the 1945 Constitution. Furthermore, Article 5 paragraph (1) of the Decree The MPR stated that "The People's Consultative Assembly examines laws against the 1945 Constitution and MPR Decrees". The Review of the Authority of the People's Consultative Assembly has never been carried out, which if it were carried out, of course it cannot be called a review because the People's Consultative Assembly is not a judicial institution. Furthermore, the important idea of examining the constitutionality of laws by a judiciary only materialized when the Third Amendment to the 1945 Constitution was ratified on November 9, 2001. Since then the idea of establishing a Constitutional Court was adopted in the Indonesian state administration system.

The Third Amendment to the 1945 Constitution has given birth to Article 24 paragraph (2) which states that "Judicial power is exercised by a Supreme Court and judicial bodies under it in the general court environment, the religious court environment, the military court environment, the state administrative court environment. , and by a Constitutional Court".

The mention of the institution of the Constitutional Court confirms the establishment of a new judicial institution which is outside the judicial environment of the Supreme Court, but at the level of its position with the Supreme Court. Then Article 24C of the 1945 Constitution explicitly mentions the scope of authority possessed by the Constitutional Court. When the Fourth Amendment to the 1945 Constitution was made in 2002, Article III of the Transitional Rules of the 1945 Constitution was ratified which stipulates that "the Constitutional Court shall be established no later than 17 August 2003 and prior to its establishment, all powers shall be exercised by the Supreme Court". This provision provides a constitutional stipulation for the establishment of the Constitutional Court because there is a clear time limit for its formation.

On August 13, 2003, Law Number 24 of 2003 concerning the Constitutional Court was passed. The Constitutional Court Law specifically further regulates the position, composition and powers of the Constitutional Court, the considerations and considerations of the Constitutional Court as well as the procedural law. With the ratification of the Law on the Constitutional Court, recruitment and consideration are then carried out to evaluate Constitutional Justices through three channels, namely the House of Representatives, the President, and the Supreme Court. On August 15, 2003, slowly nine Constitutional Justices were appointed by Presidential Decree No. $147 / \mathrm{M}$ of 2003 , which was then followed by taking the oath of office and nine 
Constitutional Justices on August 16, 2003. Then on August 19, 2003 the Constitutional Justices began carry out login. On that same date, for the first time through a closed session, Jimly Asshiddiqie was elected as the Chairman of the Constitutional Court and M. Laica Marzuki as the Deputy Chairman of the Constitutional Court.

According to Jimly Asshiddiqie, when the Constitutional Court only had three pieces of paper as capital, namely the 1945 Constitution made by the People's Consultative Assembly, the Law on the Constitutional Court made by the House of Representatives, and the Presidential Decree on the Appointment of Constitutional Justices made by the President. Currently, the Constitutional Court has been relatively successful in carrying out institutional and capacity building because it already has complete infrastructure and facilities that are very adequate to become a judicial institution.

\section{b. Position and Functions of the Constitutional Court}

Theoretically related to the purpose of law, that "Legal products that have begun to be applied philosophically can be stated as an attempt at theory about law and theory about lawmaking, and try to unite them with an idea that ultimately solves the same problem with the task of producing a perfect one. who must stand firm forever.

the existence of the Constitutional Court, is an effort to solve problems in the field of law. Clearly, the position of the Constitutional Court is stated in Article 2 and Article 3 of Law Number 2 of 2003 concerning the Constitutional Court. Article 2 states that "The Constitutional Court is one of the state institutions exercising independent judicial power to administer justice for law and justice". Then Article 3 states that "The Constitutional Court is domiciled in the Capital of the Republic of Indonesia".

The Constitutional Court has a strong and high position in the Indonesian state administration system. It is said to have a strong position because the Constitutional Court has a constitutional backing through the 1945 Constitution. Meanwhile, it is said to have a high position because the Constitutional Court is a high state institution and as a separate judicial institution. The Constitutional Court is equal to the Supreme Court. The difference between the Constitutional Court and the Supreme Court lies in the authority they have. In carrying out its duties, the Constitutional Court must act as a "judex factie", which is to be actively involved in examining facts on the ground. Meanwhile, the Supreme Court only acts as a "judex juris", that is, it only examines case files and pays attention to aspects of law application in lower court decisions.

Judicial power in Indonesia can be called a bifurcation system (bifurcation system) or a dualist structure, because the actors of judicial power are divided into two branches, namely the ordinary judicial branch which culminates in the Supreme Court and the constitutional court branch which is carried out by the Constitutional Court. Although the Supreme Court and the Constitutional Court are actors of equal judicial power, they have different competencies and competencies. However, when viewed from its authority, the Constitutional Court appears to have a "slightly higher" position than the Supreme Court. This can be seen, for example, in Article 55 of Law Number 24 of 2003 concerning the Constitutional Court which states that "The examination of laws and regulations under the law that is being carried out by the Supreme Court must be stopped if the law that is the basis for testing The regulation is in the process of being reviewed by the Constitutional Court until a decision by the Constitutional Court is reached". In its position as a judicial institution whose authority intersects with constitutionalism and state administration, there are five functions that are usually attached to the Constitutional Court, namely:

1) The Constitutional Court works as a Constitutional Guard so that the supremacy of the constitution can be upheld.

2) The Constitutional Court works as a Decision Controller based on a democratic system.

3) The Constitutional Court is the only interpreter of the Constitution (the only or the highest interpreter of the Constitution) which has binding legal power.

4) The Constitutional Court performs its function as the Protector of Constitutional Rights.

5) The Constitutional Court as the Protector of Human Rights.

According to Hans Kelsen, in the context of examining laws on top of the constitution, the Constitutional Court works as a negative legislator, that is, overriding and even making laws that are proven to be contrary to the constitution. This is done by the Constitutional Court through its decision that is binding on all parties (erga omnes), even though the request for the decision is filed by only one or several people. As a judicial institution that functions as a negative legislator, the Constitutional Court is a counter-balance to the House of Representatives that works as a positive legislator, namely the institution that makes and ratify laws. The difference between the two lies in the recruitment procedure. Constitutional Justices are officials of high state institutions who are appointed while members of the House of Representatives are high state institutions elected through general elections.

Constitutional judges who are not elected through general elections use a law made by members of the House of Representatives who are elected through general elections. This means that only five Constitutional Justices out of nine Constitutional Justices can declare the material of a law, either in part or in whole, does not 
have legal force and is not binding on the public if the material of the law is contrary to the 1945 Constitution. This is possible because the Indonesian state administration system implements the supremacy of the constitution which the Constitutional Court is the guardian of the supremacy of the constitution. Constitutionally, the Constitutional Court is a legal organ (Organ des Rechts) and not as a political organ (Organ der Politics). The numbers given by the Constitutional Court are actually closely related to politics and therefore the decisions handed down by the Constitutional Court have political influence or impact, even though the decision-making process at the Constitutional Court is a legal process and not a political process. That is, the Constitutional Court is basically a state institution that is very close to the political dimension, even though the function that must be carried out is a legal area. As an independent and impartial judiciary, of course the Constitutional Court must be independent and neutral from all forms of political influence and partisanship.

\section{Closing}

Based on this brief study, the authors can conclude that philosophically, the Constitutional Court has a very strategic position and function in the Indonesian constitutional system. With a successful strategic position and function, the Constitutional Court is able to influence and even determine legal findings through the practice of constitutionalism through the examination of laws submitted to the Constitutional Court and at the same time political life in Indonesia.

\section{BIBLIOGRAPHY}

\section{Books}

Achmad Roestandi, 2006, Mahkamah Konstitusi dalam Tanya Jawab, Sekretariat Jenderal dan Kepaniteraan Mahkamah Konstitusi RI, Jakarta.

Edi Suryono, 2013, Regulasi Hukum ,Politik dan Demokrasi, Wacana Media Press, Bandung.

Faisal Santiago, 2007, Pengantar Hukum Bisnis,Cintya Press, Jakarta.

Hermanto, 2018, Demokrasi dan Negara Hukum,Dharmawangsa Press, Surabaya.

Hermasyah, 2015, Demokrasi di Negara Hukum, Cakra Media Press, Surakarta.

-------, 2017, Pengantar Filsafat Hukum, Jakal Press, Yogyakarta.

Irmawan, 2017, Supremasi Hukum Era Reformasi,Cempaka Media, Jakarta.

Jimly Asshiddiqie, 2006, Konstitusi \& Konstitusionalisme Indonesia, Sekretariatan Jendral dan Kepaniteraan Konstitusi RI, Jakarta,

Joko Pranowo, 2016, Kedudukan Hukum Mahkamah Konstitusi, Pena Media, Jakarta.

Moh. Mahfud MD, 2000, Membangun Politik Hukum, Menegakkan Konstitusi, LP3ES, Jakarta.

Saldi Isra, 2010, Pergeseran Fungsi Legislasi: Menguatnya Model Legislasi Parlementer dalam Sistem Presidensial Indonesia, RajaGrafindo Persada, Jakarta.

Salim, 2015, Perkembangan Teori Dalam Ilmu Hukum, Rajawali Pers, Jakarta.

Sudarman Daryanto, 2017, Pembangunan Hukum Nasional, Pamator Press, Jakarta.

Surya Bintoro, 2020, Hukum Acara Mahkamah Konstitusi, Cempaka Press, Jakarta.

Suswanto, 2016, Kedudukan Hakim Konstitusi Dalam Sistem Peradilan di Indonesia, Cempaka Media, Jakarta.

Yuliandri, 2009, Asas-Asas Pembentukan Peraturan Perundang-Undangan yang Baik: Gagasan Pembentukan Undang-Undang Berkelanjutan, RajaGrafindo Persada, Jakarta

\section{Laws and regulations}

Indonesia, Undang-Undang Dasar Negara Republik Indonesia Tahun 1945

--------, Undang-Undang Republik Indonesia Nomor 24 Tahun 2003 tentang Mahkamah Konsitusi 